\title{
The booming economics-made-fun genre: more than having fun, but less than economics imperialism
}

\author{
JACK J. VROMEN \\ EIPE, Erasmus University Rotterdam
}

\begin{abstract}
Over the last few years there seems to have been a sharp increase in the number of books that want to spread the news that economics is, or at least can be, fun. This paper sets out to explain in what senses economics is supposed to be fun. In particular, the books in what I will call the economics-made-fun genre will be compared first with papers and books written by economists with the explicit intent of making fun of economics. Subsequently, it will be examined whether or not it makes sense to accuse books in the economics-made-fun genre of economics imperialism, as some commentators have recently done.
\end{abstract}

Keywords: economics-made-fun, pop economics, freakonomics, economics imperialism, sociology of economics

JEL Classification: A11, A13, A14

In the wake of Levitt and Dubner's best-selling Freakonomics (2005) there has been an upsurge in the publication of similar books. Tim Harford's (2005) The undercover economist and The logic of life (2008), Steven E. Landsburg's (2007) More sex is safer sex, Tyler Cowen's (2007) Discover your inner economist, Robert Frank's (2007) The economic naturalist, and Diana Coyle's (2007) The soulful science are cases in point. Freakonomics was not the first book in this genre. It was preceded by books like Steven Landsburg's (1993) Armchair economist, David Friedman's (1996) Hidden order, John Kay's books (such as his 2003 book The truth about markets), and Charles Wheelan's (2002) Naked economics. But the success of Freakonomics surely provided the strongest impetus to the genre.

AUTHOR's NotE: This paper is an outgrowth of the research I did for my inaugural lecture at Erasmus University Rotterdam, Faculty of Philosophy, November 2008: http://publishing.eur.nl/ir/repub/asset/13915/Inaugurale\%20rede\%20Vromen.pdf. My thanks go to the editors of this journal for making useful comments and suggestions. 
Can we really speak of a distinct genre here and, if so, what are its defining and distinguishing features? All the books mentioned above are popularizing books. They all try to reach a broader audience of nonspecialists. And most of them want to report on new and sometimes path-breaking research at the frontiers of the discipline of economics. In short, they all want to impart the typical economic way of thinking in general and recent particular developments in economic theorizing to the non-cognoscenti.

Several labels have been proposed for this genre. On Amazon Listmanias, we find 'economics made fun', 'pop economics', ${ }^{2}$ and 'cuteo-nomics', ${ }^{3}$ as alternative labels for roughly the same sets of books. Since both 'pop economics' and 'cute-o-nomics' have negative, pejorative connotations and I do not want to start my discussion from the outset with such clearly value-laden labels, I opt for the more neutral 'economics made fun' label, and consider all the books set out above as attempts to show to non-economists that doing economics can be fun.

It is not so clear where to draw the boundaries of the economicsmade-fun genre. Lately several books have been published that aim specifically at popularizing behavioral economics. Dan Ariely's (2008) Predictably irrational is perhaps the clearest example, but Thaler and Sunstein's (2008) Nudge, Hallinan's (2009) Why we make mistakes, Jonah Lehrer's (2009) How we decide, and Peter Ubel's (2009) Free market madness can be mentioned here as well. As behavioral economics selfconsciously sets itself apart as different from and in several ways critical of standard economic analysis, it can be argued that these books comprise a genre of their own. On the other hand, the books in the economics-made-fun genre mentioned above are typically less critical of standard economic analysis, though they all also do take at least some ideas and insights from behavioral economics on board. For convenience, I will simply assume that the books that specifically popularize behavioral economics do not belong to the economics-madefun genre.

Once one starts looking more closely and in greater detail into the books that clearly do belong to the economics-made-fun genre, real and profound differences between them meet the eye. For instance, unlike the other books, Cowen's is in the tradition of self-help books: it

\footnotetext{
${ }^{1}$ See http://www.amazon.com/Economics-Made-Fun/lm/R2FOSXD5EFEA17

See http://www.amazon.com/Pop-Economics/lm/R29R7RXDYXGUQU

${ }^{3}$ See http://www.economist.com/blogs/freeexchange/2007/07/whats_wrong_with_cuteonomics.cfm
} 
contains practical tips for how to live a better life. In contrast, Levitt and Dubner's Freakonomics mostly gives a highly readable exposé of "clever" academic economics papers written by the "maverick" economist Stephen D. Levitt and various co-authors. As several commentators have observed, there is not much explicit use of economic analysis in Freakonomics. Levitt and Dubner themselves explicitly declare that much in their book is the result of what they call an "honest assessment of the data”. By contrast, Frank's (2007) book consists of little more than an informal discussion of the basic principles of economic analysis and how they can be put to use in explaining everyday enigmas.

Yet, despite their differences, I believe books in the economicsmade-fun genre all have a few things in common with each other. They all hold that economics can be fun in the following three senses:

1. The basic principles and tools of economic theory are presented in a "light", informal, accessible and entertaining way. Mathematical equations and graphs, with which standard textbooks for introductory economics courses are replete, are conspicuously lacking. The key idea is that the gist of economic principles and their use in explanations of all kinds of phenomena can be taught and understood as well, and perhaps even better and more easily, without invoking esoteric formal language.

Robert Frank especially, in his The economic naturalist, is most explicit in promoting what he calls the narrative 'less-is-more' approach to teaching economics. According to the narrative theory of learning, there is no better way to master and remember an idea than to see the idea in action in a catchy story. And the 'less-is-more' approach to learning is based on the insight that to get profound and lasting learning effects, it is better to teach just a few basic principles in economics in verbal form than to try to get the full panoply across with the aid of algebra and graphs.

In short, what is fun here is the way in which the core elements of economic analysis are presented. Economics is not just for autistic nerds. It can be wrapped up in such gripping ways that it also appeals to the most social, literate, and popular guy in high school. Since this sense in which economics can be fun pertains to how it is presented rather than its contents, let's call this sense: 'pimp your economics'.

2. The basic principles and tools of economic theory can be used to explain all kinds of interesting subjects, topics, questions, and phenomena. And, indeed, the scope of the subjects addressed in these 
books is astoundingly wide, reaching far beyond what are traditionally called economic phenomena. In fact, the subjects tackled are most of the time everyday phenomena that would traditionally be called noneconomic. One of the more serious issues discussed in Levitt and Dubner's Freakonomics, for example, is the relationship between the legalization of abortion and criminality. Other issues are more trivial and frivolous, such as what sumo wrestlers and school-teachers have in common, and why drug dealers still live with their moms. Issues addressed in other books in the economics-made-fun genre range from why milk cartons have a rectangular shape while cola cans are cylindrical to why more sex is safer sex.

The fun here lies in the sorts of subjects addressed in economic analyses; they are taken to be more exciting and interesting than the supposedly dull or boring issues that are traditionally dealt with in economics. Thus, we could call this sense: 'economics used to tackle really interesting issues'.

3. The basic principles and tools of economic theory can be used to reveal the hidden side of all kinds of phenomena. In books in the economics-made-fun genre it is often argued that economic analysis is needed to look beneath mere appearances and uncover how things really are. "Conventional wisdom" - how things look at the surface - is often derided and taunted. Landsburg especially seems to have great "devilish" fun in debunking popular myths. Contrary to what is commonly believed, for example, Landsburg (1993) provocatively argues that seat belts kill rather than save lives. And, as the title of his book already indicates, Landsburg (2007) argues that more sex is safer sex.

The fun here is with the sorts of insights yielded by economic analysis. Economic analysis allows you to see what is really going on underneath. What is especially supposed to be fun is to tear folk wisdom to pieces. We could call this sense: 'economics reveals the truth they do not want you to know'.

For protagonists of the economics-made-fun genre, the three senses in which economics can be fun are related. They believe it is important to make "thinking as an economist" accessible to a larger audience, because they believe that thinking as an economist often leads to important unorthodox insights into a variety of interesting issues. In principle, what is aimed at could be no more than teaching standard economic theory to economics students in a more juicy, entertaining and engaging way (to bring it in line with the prevailing demands of pop 
culture, for example). But in fact the further aim is to make the general public more economically literate. The general thrust is that there is a lot to be learned for everyone from using economic principles to explain all kinds of phenomena, and not just phenomena that are traditionally deemed economic. That contributes to an enhanced understanding of the world around us. In short, the overarching aim is to enlighten the general public about the hidden economic side of everyday phenomena.

\section{ECONOMICS-MADE-FUN GENRE VS ECONOMISTS-CAN-BE-FUNNY GENRE}

The economics-made-fun genre is not to be confused with what could be called the economists-can-be-funny genre. ${ }^{4}$ Papers in the economistscan-be-funny genre such as Blinder (1974), Krugman (1978), and Harbaugh (2003) are primarily meant to amuse mostly felloweconomists. Such papers poke fun at serious academic economics papers by parodying them and can be said to provide a healthy dose of self-mockery. In them, economists show some awareness of the limitations, weaknesses, and shortcomings of their own analyses.

Krugman (1978), for example, presents his paper as "[...] a serious analysis of a ridiculous subject, which is, of course, the opposite of what is usual in economics". Apparently, Krugman believes that though the subjects addressed by economics are normally important ones, the analyses of them given in economics should not be taken too seriously. This seems to be almost the opposite of what protagonists of the economics-made-fun genre are arguing. They seem to argue that economic analyses are always serious and that they should be taken (more) seriously by the larger public, but that the subjects addressed by economics have often not been very interesting. They set out to show that economic analyses of more interesting subjects, including (and perhaps even in particular) those that are not traditionally addressed by economics, are insightful and revealing.

That economists can be funny, especially by making fun of their own discipline, is also demonstrated by the world's first stand-up economist, Yoram Bauman. ${ }^{5}$ Unlike some of the critiques expressed by practitioners of other social sciences or philosophy, Bauman's tone is not condescending, vitriolic, or scornful, but light, playful and understanding. What is more, Bauman's jokes display a thorough

\footnotetext{
${ }^{4}$ See http://petermartin.blogspot.com/2009/01/can-economists-be-funny.html

${ }^{5}$ See, for example, http://www.youtube.com/watch?v=YgB6mFmYEcM For more details visit http://www.standupeconomist.com/
} 
understanding of economics and its basic principles. ${ }^{6}$ It is perhaps telling that Bauman's performance is especially popular amongst fellow economists. This might strike an outsider as odd and perhaps even as cynical and irresponsible, but, as the numerous economics jokes documented by Clotfelter (1997) show, economists have a long and venerable tradition of making fun of the very principles they themselves use in their work on a daily basis. Unlike some of their critics, many economists see no contradiction between being open and explicit about the limitations and shortcomings of their own discipline and continuing to use its basic principles.

An exchange between Oxoby and Levitt shows in a hilarious way what can happen when these two genres are mixed up. In the University of Calgary Department of Economics Discussion Papers Series, Robert J. Oxoby (2007) published a paper under the title "On the efficiency of AC/DC: Bon Scott versus Brian Johnson". In the paper it is observed that it is difficult to ascertain who in the hard-rock band AC/DC was the better vocalist, Bon Scott or Brian Johnson. Yet, Oxoby argues, some experimental findings suggest that Brian Johnson was the better vocalist. When the AC/DC song "Shoot to thrill" (with Brian Johnson as the vocalist) was played, more efficient outcomes were realized in an ultimatum game experiment than when the AC/DC song "It's a long way to the top" (with Bon Scott as the vocalist) was played. Whereas the offers by the proposers were rejected five times by the respondents when they heard Bon Scott sing, the offers were rejected only three times when they heard Brian Johnson sing. Although Oxoby's paper is relatively short (it is seven pages long, or four pages without references), it has the usual format of an academic economics paper and is replete with standard economics jargon.

When Oxoby's paper was brought to his attention, Levitt's response was: "They grow up to write economics papers like this one, which looks at whether participants in lab experiments get closer to efficient outcomes when exposed to one lead singer of the rock band AC/DC versus another. I hope for this guy's sake he has tenure" (Levitt 2007a). Understandably, Oxoby was not amused by Levitt's denigrating response. In his response to Levitt, Oxoby hastened to make clear that his paper was meant to be a joke. Oxoby seems to be genuinely puzzled that this had not been immediately clear to everyone. He was unpleasantly surprised in particular by Levitt's non-understanding and

\footnotetext{
${ }^{6}$ See http://www.youtube.com/watch?v=VVp8UGjECt4
} 
denunciation: "I would think that you of all people would recognize a joke when it comes up" (Oxoby 2007). Oxoby's tacit assumption seems to be that Levitt's own specialty is to tell economic jokes. That at least would explain why Oxoby was surprised that Levitt "of all people", failed to recognize Oxoby's paper as a joke. But such an assumption seems to be false. Freakonomics is not meant to be a compilation of economic jokes. Far from it; the economic analyses of "freakish phenomena" in Freakonomics are meant to be dead serious. It seems that Oxoby mistook Levitt and Dubner's book in the economics-madefun genre for a book in the economics-can-be-funny genre.

I think there is no doubt that Oxoby meant his paper to be a joke, but Levitt did not realize that. Why not? Of course, it might be that Levitt simply did not pay enough attention to the paper. I think that would leave Levitt with a bit of explaining to do for why he nevertheless thought he could write such condescending lines about it (and, even worse, about Oxoby himself). Alternatively, might it be that Levitt takes all economic analyses, or all papers that superficially have the appearance of a serious economics paper, way too seriously, even if they, like Oxoby's, are meant to be a pastiche of them? It seems Levitt lost a sense (or never developed it in the first place) for distinguishing work that is meant to be taken seriously from work that is only intended to provoke a good laugh-this is what McCusker (2007) suggests. Levitt found Oxoby's paper deficient and wanting on the incorrect presupposition that published work by economists is always meant to be taken seriously.

What is perhaps most puzzling in the Levitt-Oxoby exchange is that Levitt, in his response to Oxoby's response, argues that Oxoby still owes us an explanation or, rather, justification for why he conducted the experiment in the first place: "I still think this leaves Professor Oxoby with a bit of explaining to do as to why they were playing AC/DC as part of an experiment in the first place, however" (Levitt 2007b) Now, isn't that funny? Here is someone who seems to tackle and write publishable papers on whatever lends itself to a clever treatment demanding that someone else justify his choice of subjects. Who is Levitt, with his panoply of "freakish curiosities", to demand a justification from other economists for their choice of non-standard subjects? My point here is not that Levitt's (let's call it a) request to Oxoby is outrageous. I think it is a fair question. What is the point of playing AC/DC as part of an experiment? What sorts of insights did they hope to extract from the 
experiment? But that Levitt "of all people" is making such a request is really funny.

Oxoby wrongly assumed that Levitt's work was part of the same economists-can-be-funny genre as his own AC/DC paper. But Levitt's work is part of a different, economics-made-fun genre. The misunderstanding appears to have been mutual. Levitt initially seems to have assessed Oxoby's paper on the assumption that Oxoby's paper also belonged to the economics-made-fun genre. Had Oxoby been aware of this, Levitt's dismissive response probably would not have surprised him. What perhaps still would have surprised Oxoby is that Levitt, who after all can be called the master of picking "freakish curiosities", calls on Oxoby to justify his choice of subject. It might be that Levitt considers Oxoby's subject to be not only unimportant but also simply uninteresting. I think that Oxoby would readily agree that the subject of his paper is ridiculous rather than interesting (let alone important). Perhaps the interesting issue here is not why Oxoby wanted to parody serious academic economics papers in the economics-can-be-funny genre, but why it was accepted as a University of Calgary Economics Discussion Paper. It seems Oxoby could earn academic kudos very easily and leisurely in some lost hours in an airport by turning the failed experiments of his grad student into a joke paper. Perhaps this tells us something about prevailing opportunities and incentives in the economics profession, a topic to which I shall return shortly.

\section{THE ECONOMICS-MADE-FUN GENRE IS NOT ECONOMIC IMPERIALISM}

The aims of the economics-made-fun genre should not be confused with those of the economists-can-be-funny genre. Whereas books and papers in the economists-can-be-funny genre are meant not to be taken seriously, books in the economics-made-fun genre are meant to be taken very seriously by their authors. If all that the books in the economicsmade-fun genre would bring about in their readers were just a jolly bout of laughter or a wry smile, protagonists of the economics-made-fun genre would be deeply disappointed. Their readers are supposed to learn a lot about the hidden side of virtually everything.

In the economics-made-fun genre, economic analysis is used to shed light on "outlandish" phenomena that clearly do not belong to what is traditionally taken to be the economic domain. Furthermore, the insights thus obtained are sometimes compared with and virtually always found superior to the insights obtained in the social sciences 
that traditionally cover such "outlandish" phenomena. Does this imply, as Rubinstein (2006), and Fine and Milonakis (2009) suggest, that Freakonomics (and other books in the economics-made-fun genre) display economics imperialism at work?

Fine and Milonakis argue that Freakonomics is economics imperialism driven to the extreme. Fine and Milonakis start by introducing "economics imperialism" in rather neutral terms as "[...] the extension of economic analysis to subject matter beyond its traditional borders" (Fine and Milonakis 2009, 7). Economics imperialism is thus depicted as an outwards pushing movement: by subjecting ever more "outlandish" subjects to economic analysis, economics pushes its borders in an outward direction. Freakonomics is depicted by Fine and Milonakis as the crowning achievement of economics imperialism to date, following earlier episodes of what they call old- and neweconomics imperialism. Unsurprisingly, they take Gary S. Becker, with his attempts to apply "the economic approach" to a variety of "noneconomic" subjects, to be the main spokesman of old-economics imperialism.

Fine and Milonakis identify George A. Akerlof and Joseph Stiglitz as leading protagonists of new-economics imperialism. This might surprise some, since Akerlof's work especially is regarded by many as exactly the opposite of economics imperialism. Instead of using Becker's economic approach to explain phenomena outside the traditional homeland of economics (henceforth "outlandish phenomena"), in much of his work Akerlof tries to amend Becker's economic approach with concepts and insights drawn from other social sciences in order to change and improve the economic analyses of phenomena that fall squarely within economics' traditional homeland. This is acknowledged by Fine and Milonakis. Yet they argue that both Akerlof's and Stiglitz's "informationtheoretic" explanations leave basic elements of standard "marginalist" economic analysis intact (such as its commitment to methodological individualism and the assumption that individual agents maximize their own utility under constraints). These same old basic elements are used by Akerlof, Stiglitz, and others to explain ever more "non-economic" phenomena, such as social institutions. Fine and Milonakis consider Freakonomics to be the apex of this trend. Books like Freakonomics seem to claim that the scope of economic analysis is boundless. As Levitt and Dubner say "[...] no subject, however offbeat, need be beyond its reach" (Levitt and Dubner 2005, 12). 
In their book, however, Fine and Milonakis go well beyond the neutral terminology of economists reaching outwards beyond economics' traditional borders by speaking of economists "invading" foreign territory that is already "occupied" by others, "conquering" and "colonializing" their denizens, and "appropriating" and "exploiting" their resources. In calling Freakonomics a typical work in academic imperialism, Rubinstein (2006) draws attention primarily to the latter "inwards pulling" tendency in Freakonomics: economists are searching for "interesting questions" as "natural resources" that they can exploit. Thus it seems that "economics imperialism" is associated with two opposite movements. Whereas Fine and Milonakis primarily emphasize the expansionist tendency in Freakonomics (economists reaching out to conquer other social sciences), Rubinstein stresses that Freakonomics reflects a search by economists for "outlandish" subjects that they can appropriate.

Do notions such as "conquering" or "appropriating" aptly and accurately capture what is driving the Economics Made Fun movement? Let us first discuss "appropriating" and then turn to "conquering".

\section{Exploitation and appropriation?}

One could argue that at bottom the two opposing movements of "conquering" and "appropriating" are manifestations of the same phenomenon: by pulling in subjects that are traditionally addressed by other social sciences, economics is pushing its boundaries outwards. One could also argue that the latter is instrumental to the former: economics is pushing its boundaries outwards in order to have easy, cheap and continuous access to new resources drawn from abroad. This presupposes that subjects (and issues and phenomena in general) can be appropriated by some discipline in a similar way as natural resources in some territory, such as oil and gas, can be appropriated by some foreign country or company. But are the subjects tackled or addressed by some discipline like that? If economists start tackling "outlandish" phenomena, are other disciplines that traditionally tackled these phenomena thereby denied access to them? It seems not. Unlike natural resources, which are private goods, subjects are more like public goods. Their "use" by the one discipline does not diminish the opportunities for other disciplines to "use" them. Disciplines cannot be dispossessed of their subjects in the same way that countries can be dispossessed of their natural resources. 
Furthermore, on closer inspection seemingly clear phrases such as "subjects that traditionally are regarded as falling outside the economic domain" appear to be not at all that clear. Consider subjects such as social institutions, social norms and social structure. At first sight we might be inclined to say that these traditionally belong to the domain of sociology rather than that of economics. On this view, any use of economic analysis by an economist to shed light on them is seen as an extension of the economic domain. But what about firms, for example, and the ways in which they are internally organized? Firms can be seen as institutions and there is undeniably social structure in the ways they are internally organized. Yet most onlookers would say that firms and their behavior belong squarely to the economic domain (or, simply, to the economy).

Our economies are replete with "sociological" (and also "psychological") phenomena. As Simon (1991) once famously remarked, if an extraterrestrial visitor had a look at our economies, its attention would probably be drawn more to production processes within firms than to the exchanges between firms (and between firms and households) in markets. One way to read Coase's (1937) classic (and the work of the new-institutionalist economists such as Williamson that followed) is that by bringing analyses of the nature and boundaries of firms back into economics, Coase put an end to the scandal that (the then prevailing) standard economic theory had not much to say about firms. In other words, much of what is going on in Fine and Milonakis's new-economics imperialism, which they describe as economists appropriating and exploiting phenomena from other disciplines, can also be described as economics regaining economic subjects that they seemed to have lost.

Fine and Milonakis regard not only the explanation by economists of outlandish phenomena (or subjects, or problems), but also the "exploitation" by economists of concepts from other social sciences as economics imperialism (Fine and Milonakis 2009, 123). Thus, apparently, if economists try to accommodate concepts such as "identity" and "fairness" into their analyses in order to enrich and improve them, for Fine and Milonakis this testifies to their economics imperialism. I think Fine and Milonakis conflate two different issues here. One issue is whether using concepts such as appropriating and exploiting does justice to what is going on when economists incorporate concepts from other disciplines into their own analyses. The other issue 
is to what extent economists are indebted to other disciplines and whether the way in which they accommodate insights drawn from other disciplines does justice to "the real world". Whereas the second issue is a serious and interesting one (more on this below), I think the first issue can be resolved quickly: no, it does not make sense to describe what is going on in terms of appropriation and exploitation. Economists do not steal anything from other social sciences nor abuse them in any other sense by using their concepts.

In fact, this could be called the exact opposite of economics imperialism: instead of economic analysis finding its way into other social sciences, concepts from sociology and psychology find their ways into economic analysis. If one insists on calling this a form of academic imperialism, 'sociology imperialism' or 'psychology imperialism' would be more apt than 'economics imperialism': sociology or psychology have been successful in getting their concepts established in economic analysis. I think it would be even better, however, to abstain from talking of imperialism altogether here. Sociologists and psychologists did not force or impose anything on economists. Economists have voluntarily accommodated concepts from sociology and psychology, whatever specific reasons they might have had for doing so.

\section{Conquering?}

I have argued that notions such as "appropriation" and "exploitation" misrepresent the way in which alleged economics imperialists search for subjects and concepts in other social sciences. Is saying that alleged economics imperialists try to conquer other social sciences more accurate? Are these economists driven by the explicit intention to dominate other social sciences, to rule them, or to subject them to economics' hegemony? The image of economic analysis conquering other social sciences might seem most accurate for the first stage of economics imperialism that Fine and Milonakis distinguish, and which they dub old-economics imperialism. Witness Stigler's warlike proclamation: "So economics is an imperial science: it has been aggressive in addressing central problems in a considerable number of neighboring social disciplines and without any invitations" (Stigler 1984, 311). Economists are portrayed here as unsolicited intruders, eager to wipe out non-economic analyses in other social sciences. But it is not clear that Stigler's proclamation is representative even of first stage oldeconomics imperialism, let alone of later phases of economics 
imperialism. There is no clear evidence that its protagonists made sustained efforts to promote the spread of economic analysis into other social sciences. There is only some evidence that they made sustained efforts to get economic analyses of "outlandish" subjects accepted in their own discipline.

Lazear (2000) provides a sympathetic overview of the accomplishments of specifically old-economics imperialism. In line with standard economic theory, Lazear argues that in order to tell whether or not it has been successful, "economics imperialism" should be subjected to the market test (Lazear 2000, 104). Its success should be measured in particular in terms of the increase in the market share of economic analyses in other social sciences and in terms of how many economists have replaced non-economists (have forced non-economists out of business, in Lazear's own terms) in the other social sciences. This seems to make sense: what should be looked into is whether economic analyses have been used more often in leading journals in other social sciences and whether economists have increasingly taken the positions of non-economists (in faculties and departments of other social sciences, for example). However, even if it turned out that there has been an increase on both counts, this by itself would of course not testify to the success of economics imperialism per se. An increase need not be due to the deliberate efforts of economists and especially of economics imperialism's protagonists to increase the market share of economic analysis and of economists in other social sciences. Practitioners of other disciplines could have come to the conclusion that economic analysis is useful for them independently of such efforts. For example, Paul Glimcher, Michael Dorris, and Hannah Bayer's (2005) version of neuroeconomics seems to be a case in point (see, Ross 2008 and Vromen 2007). Nevertheless, if the market tests showed a clear increase in the market shares of economic analysis and of economists in other disciplines, the data would at least be consistent with the hypothesis that the protagonists of economics imperialism have succeeded in what they are after.

As it happens, however, Lazear has not conducted either market test (nor has anyone else, as far as I know). Instead, Lazear discusses many examples of papers published in economics journals in which economists have used economic analysis to shed light on "outlandish" subjects. With only a few exceptions, most papers mentioned in Lazear's references are published in prestigious economics journals such as the 
American Economic Review, the Journal of Political Economy and the Quarterly Journal of Economics. Thus, instead of measuring changes in the market share of economic analyses in non-economics academic journals, Lazear seems to be reporting mainly on the increased market share of economic analyses of "outlandish" subjects in leading economics journals. Strictly speaking, the only thing Lazear shows is that economics imperialism has been successful in economics. There has become more room for, and acceptance of, this sort of work in the profession of economics. Becker's type of work might have been controversial among economists even at the time he was awarded the Nobel Prize, but it seems it has become less controversial ever since.

\section{Mutual disdain?}

Saying that clear evidence is lacking that economics imperialists are driven by the desire to conquer other social sciences is not to say, of course, that they would not be delighted if the market share of economic analysis and of economists in other social sciences were to increase. To be sure, proponents of the economics-made-fun genre occasionally express dissatisfaction with, and sometimes even disdain and contempt for other social sciences. In Freakonomics there is quite some sneering at "experts", which include, according to Levitt and Dubner, practitioners of other social sciences who mostly repeat "conventional wisdom" based on moralistic wishful thinking rather than an honest assessment of the data. Fine and Milonakis argue that the typical attitude of economists towards other social sciences can be characterized as parasitic, arrogant, ignorant and contemptuous (Fine and Milonakis 2009, 122-126). Though this might be a bit harsh and overblown, I think Fine and Milonakis are right that the average economist does not hold the scientific achievements and credentials of other social sciences in high esteem.

Disdain for other social sciences does not seem to be restricted to economists, however. The disdain that economists feel towards other social sciences seems to be mutual. Practitioners of other social sciences often loath or poke fun at the narrow-mindedness of economics as a discipline. The economic conception of humans and their behavior in particular-the infamous homo economicus - is taken to be a grotesque caricature and simplification of how people of flesh and blood really are and really behave. 
The subfield of economic sociology seems to be especially interesting in this respect. Much of what is currently going on in economic sociology arguably takes issue with and wants to compensate for the narrow-mindedness of economic analysis in economics' own traditional homeland. In fact, many take economic sociology to be an antidote to economics imperialism. In particular, the economic conception of humans and their behavior is taken to be "undersocialized". Mark Granovetter's (1985) plea for the explicit recognition of the social embeddedness of persons and their actions is a well-known case in point.

Many economists feel that their discipline (and especially standard economic analysis) is badly misrepresented in the (economic) sociologists' critique of economics. This feeling is not restricted to economists who believe there is nothing wrong with standard economic analysis. It is shared by some economists who are open and even sympathetic to the suggestion that standard economic analysis has its limits and shortcomings and that economic analysis can be enriched and improved by bringing in concepts, ideas and insights from (economic) sociology. Gibbons (2005) notes that the typical reaction of economists to the critique of economic sociologists is to point out that they get economics wrong. Even economists who could readily agree that the basic thrust of a critique is compelling tend to concentrate on how economic analysis is misrepresented in the critique rather than on the constructive suggestions it makes for how to enrich and improve economic analysis.

\section{Combating the dismal science image}

The economics-made-fun literature similarly seems to be more a protest against what is taken to be a misinformed and unfair image of their own discipline than an attempt to conquer and rule over other social sciences. Economics-made-fun economics first and foremost wants to enlighten the general public about the breadth and power of economists' analysis, and practitioners of other social sciences seem to be part of their intended audience. Their primary "collective" concern thus seems to be to boost the public image of economics. They seem to be fed up with the dreadful image of "the dismal science" that in their opinion still haunts economics. They believe economics never was such a dismal science in the first place, and, given all kinds of new 
developments in economic theorizing, this characterization is more inapt than ever.

This is most clearly visible in Diana Coyle's (2007) The soulful science. Coyle sets out to show that current economics, and especially cutting edge research at the frontiers of the discipline, is not at all like the dismal science that many still take economics to be. As she puts it succinctly: "The popular unpopularity of economics rests on perceptions that are twenty or thirty years out of date and were always a bit of a caricature anyway" (Coyle 2007, 2). What current economics has to say about the problems of economic development is discussed in the first part. In the second part of the book Coyle turns to recent developments in micro-economics. One of the things Coyle want to show here is that leading economists have moved far away from the models of selfish, calculating individuals that many onlookers think still populate economic analysis.

Coyle thus confines her attention to economic analyses of subjects that are traditionally considered to be key economic subjects. In other economics-made-fun books economic analyses of "outlandish" phenomena take center stage. Yet they also aim to inform a large audience about what economic analysis really is and what economists really do nowadays. And, indeed, the number of A-list publications in economics journals on "outlandish" subjects does seem to have increased over the last decade. It seems economics imperialism has become even more successful in economics since Lazear published his overview. Whence this increase? In an interesting article published in The New Republic (2007), Noam Scheiber suggests that it is due to the prevailing incentive structure in the economics profession. Especially for young economists starting out, writing a clever paper on a "freakish" subject that no other economist has touched allows academic kudos to be earned more easily and quickly than trying to bring a big, important issue that the brightest minds in the profession have already worked on a tiny bit closer to full resolution. Scheiber reports that grad students are actively discouraged by their supervisors from working on problems they cannot solve in one month. Of course, working on a "freakish" subject only pays if editors of economics journals are willing to accept them for publication. Since an increasing number of influential mainstream economists have openly confessed that they find "everyday enigmas" more interesting and exciting subjects than "boring" or "dull" 
traditional economic ones such as budget deficits and exchange rates, this condition seems to be met.

On his blog, Gregory Mankiw writes that he is not worried that Freakonomics type work will drive out work on the big important issues in economics:

All research programs run into diminishing returns; eventually, all the cleverness in finding natural experiments and off-beat identification will seem less clever than it did at first. Moreover, the profession has a healthy enough set of incentives that people will keep coming back to the big questions, as long as they think they can make progress on them (Mankiw 2007).

But if all research programs face diminishing returns in due time, this must also apply to work done on big and important issues. In fact, working on big and important issues has arguably already run into diminishing returns and new scholars know it. So I think it is questionable that the prevailing incentives structure is as healthy as Mankiw takes it to be.

The picture of economics that emerges here is one of an introverted rather than extraverted discipline. Its practitioners do not step out of economics to disseminate economic analysis in other disciplines or to pursue a career outside economics. Economists rather turn to outlandish phenomena because that is where they see the best opportunities to further their own career within their profession. Insofar as there is a collective concern driving the economics-made-fun genre, it is to correct and boost the public image of economics as a discipline. In short, rather than showing an interest in invading and conquering other disciplines, economists do not seem to show individual or collective interest in affecting other disciplines. The technical term for this is 'nontuism', aptly coined by the economist Wicksteed to describe the disinterest of agents in the interests of those they interact with characteristic of purely economic relations. If this indifference makes the economics-made-fun genre look even worse than its portrait as the apex of economics imperialism, so be it.

\section{IS HOMO ECONOMICUS STILL AMONG US?}

Contrary to what Coyle argues, several commentators seem to maintain that current economics is still wedded to the view that economic agents are selfish, calculating individuals. Although they do not deny that 
economic analysis underwent several changes in the process starting from old-economics imperialism and culminating in Freakonomics, Fine and Milonakis argue that the economic analysis in Freakonomics is still committed to the view that individuals pursue their self-interest, and that they do so in an instrumentally rational optimizing way (Fine and Milonakis 2009, 107, 110). Ariel Rubinstein (2006, 1) seems to have something similar in mind when he writes: "This worldview seeks a simple explanation for the behavior of human beings that is consistent with their aspirations to attain a goal, attributing high importance to money and status and low importance to moral values." In a similar vein, Stephen A. Marglin (2008) argues in his The dismal science: how thinking like an economist undermines community that economists still assume that economic agents are obsessively engaged in 'cold' rational calculations to figure out what serves their own interest best. There is room in standard economic theory for neither intuition and 'hot' emotion nor duties, obligations, and other other-regarding concerns.

Who is right? Coyle, who argues that economics has long left behind the stage in which it was assumed that the only thing economic agents have on their minds is the conscious pursuit of their own interest? Or Fine and Milonakis, Rubinstein, and Marglin, who argue that the fictitious worlds of economists are still populated by such monomaniacal economic men? Let us have a closer look at two books in the economics-made-fun genre - Levitt and Dubner's Freakonomics and Frank's The economic naturalist - to see how people and their behavior are depicted.

As John DiNardo (2007) observes, there is not much economics in Levitt and Dubner's Freakonomics. The little economics there is in the book can be summarized by "people respond to incentives". This is a mantra that is repeated many times in the book, often to denounce the "conventional wisdom" voiced by experts. Economists traditionally focus on economic or, more specifically, monetary incentives. Raising or lowering prices by raising or lowering taxes is perhaps the best known example. In Freakonomics, however, Levitt and Dubner argue that there are two other "flavors" of incentive besides the economic one. Social incentives relate to the (alleged) fact that people do not want to be seen by others to be doing things that are deemed wrong or bad in the society or community they are part of. They do not want to feel the shame that the disapproval by others induces. Moral incentives relate to the (alleged) fact that people do not want to do things they themselves 
consider wrong. People want to avoid the pangs of guilt that they feel if they nevertheless do things that they take to be immoral. Levitt and Dubner argue that it is wrong to assume that economic incentives alone will always determine how people behave. Sometimes people seem to respond more strongly to social and moral incentives.

This at least is one way to read their discussion of Paul Feldman's bagel business. While Paul Feldman was still the head of the public research group of the US Navy (from 1962 to 1984) he started to make a habit of bringing in bagels for his colleagues. To recoup the costs, Feldman placed cash baskets with a sign with the suggested price. The collection rate was roughly 95\%. After his research institute fell under new management in 1984, Feldman decided to leave and to make a living by selling bagels to companies in a similar way as he had done before. After a while, the collection rate began to fall slowly to some 87\%. Levitt and Dubner attribute this to the fact that before, when he still worked in the same office, his presence deterred theft. Once Feldman was no longer present at the companies that he brought the bagels to, the social incentive for employees of the companies to avoid Feldman's disapproval (by duly and honestly paying the price for their bagels) ceased to exist. In the new situation, with this social incentive no longer in place and economic incentives weakly pointing in the opposite direction of more widespread cheating, only moral incentives could have prevented the remaining $87 \%$ of the employees from cheating. More generally, in the absence of social and moral incentives, Feldman's collection rates would have been much lower than they actually were.

What to make of these figures? It seems Levitt and Dubner are a bit undecided. On the one hand, it seems they want to stress that people tend to cheat whenever the stakes prompt them to do so and that in this case Feldman was the victim. After all, a decrease in the collection rate from $95 \%$ to $87 \%$ means a $160 \%$ increase in theft. It seems they also want to emphasize that social incentives (e.g. that people do not want to be observed cheating) are powerful in preventing such a large increase from occurring. But in the end Levitt and Dubner note that it cannot be denied that even in the absence of such powerful social incentives at least $87 \%$ still refrained from cheating. They observe that this seems to prove Adam Smith right: people seem to be innately disposed to act honestly. People are generally good even without enforcement.

It is not clear whether Levitt and Dubner believe that the analysis of such moral behavior falls squarely within the purview of economics. 
Their discussion of moral incentives suggests that they do think so. As argued above, Levitt and Dubner seem to argue that only moral incentives can explain why, even when not paying would not be observed by others, the vast majority of Feldman's clients continued to pay the indicated price for their bagels. At the end of their discussion of Feldman's bagel business, Levitt and Dubner argue however that "[...] the story of Feldman's bagel business lies at the very intersection of morality and economics" (Levitt and Dubner, 2005, 46). This suggests that the domain of moral behavior and the domain of economic behavior overlap only partly and hence that only part of moral behavior is amenable to economic analysis.

At any rate, it is clear that when Levitt and Dubner argue that people respond to incentives, they are not implying that these are only monetary incentives. Levitt and Dubner recognize that there are lots of things people do not do because they do not want to be ashamed of themselves (social incentives) or because they do not want to feel guilty (moral incentives). We can find a similarly broad understanding of the sorts of "costs" and "benefits" that might go into individual decisionmaking in Robert Frank's The economic naturalist. Frank's book is a collection of narratives (mostly composed by his students) in which basic economic explanatory principles are used to explain everyday enigmas. One such basic explanatory principle stands out from the rest as the mother of all economic ideas, Frank argues, and that is the costbenefit principle (Frank 2007, 10). On closer inspection, if there is one thing that becomes clear from the various ways in which the cost-benefit principle is used as an explanatory principle, it is its flexibility and generality. In its most straightforward use "costs" and "benefits" of course refer to monetary magnitudes. But "costs" and "benefits" can also be used, and actually are used in Frank's book, to refer to psychic satisfactions and dissatisfactions of various kinds.

Consider for example Frank's discussion of why women's clothes always button from the left, while men's clothes always button from the right (Frank 2007, 26-28). What is paradoxical or enigmatic about this phenomenon is that most men and women are right-handed. For righthanded people buttoning shirts from the right is easier than buttoning them from the left. So at first sight cost-benefit considerations would seem to favor buttoning from the right as the "universal" norm for both men and women. Why then do women's clothes button from the left? Frank's answer is that the social norm that women's clothes button from 
the left was already established in the seventeenth century. Ever since, it has been unattractive for individual women to buy and wear rightbuttoning clothes for basically two reasons. The first reason is practical: as women had already grown accustomed to left-buttoning clothes, it would have taken them time and effort to develop new skills and habits to switch to right-buttoning clothes. The second reason is social: given the prevailing norm of wearing left-buttoning clothes, women found it socially awkward to appear in public wearing right-buttoning "men's" clothes. Manufacturers of women's clothes either correctly anticipated that they would not sell many right-buttoning clothes or found out to their dismay that there was no market for the right-buttoning clothes they produced.

What Frank is arguing here is that the very existence of some social norm generates costs for people if they were to deviate from them. This might prevent them from doing what they would have done in the absence of the norm. This is similar to how Levitt and Dubner conceive of the working of social incentives. Note that Frank's "economic" explanation seems to be not unlike standard sociological ("structuralist") explanations of individual behavior: people tend to conform to prevailing social norms because they tend to seek the social approval of others (and try to avoid their social disapproval). In fact, all Frank and his students seem to be doing here is garbing such a standard sociological explanation in a new economic dress. That they are doing this seems to escape their attention. Neither Frank nor his students display any awareness that sociologists have been giving such explanations for ages.

Frank is famous for his own earlier work on emotions as commitment devices (Frank 1988). The key idea is that emotions such as guilt (what Levitt and Dubner call a "moral incentive") could have evolved not despite but precisely because they limit the choice space from which people choose. If some people cannot bring themselves to cheat or defect in commitment problems because their emotional dispositions prevent them from doing so, then that might allow likespirited people to selectively interact only with them (and so avoid being exploited by other-spirited, more opportunistic types). The cost-benefit principle is invoked here to explain how emotions could have evolved: thanks to their "handicap", people with particular emotions could have reaped benefits that are out of reach to opportunists. In his new book, Frank emphasizes that this use of the cost-benefit principle does not 
imply that emotionally committed people consciously invoke costbenefit considerations. On the contrary:

[...] an emotional commitment to one's spouse is valuable in the coldly rational cost-benefit calculus because it promotes fitnessenhancing investments. But note the ironic twist. These commitments work best when they deflect people from thinking explicitly about their spousal relationships in cost-benefit terms (Frank 2007, 195).

Thus economic explanations in terms of costs and benefits can be given of behavior that is not the product of conscious cost-benefit calculations.

We can conclude with Coyle, and pace Fine and Milonakis, Rubinstein and Marglin, that, appearances notwithstanding, economic analysis, as it is promoted in the economics-made-fun movement, is wedded neither to the view that agents pursue their own interests, nor to the view that agents engage (in a "coldly" rational way) in instrumental reasoning in order to attain their goals. There is room for feelings of guilt, commitments, and duties even in the economic analyses promoted by those who hold that people respond to incentives and that the cost-benefit principle is a powerful explanatory principle that can be used across the board. Those who argue to the contrary seem to underestimate the flexibility and elasticity of current economic analysis. As Herbert Gintis (2007; 2009) for example argues, (expected) utility theory and game theory are more like a language, in that they allow for the expression of many different assertions, than like a substantive theory making specific determinate assertions about the real world. And, indeed, this is exactly how Gintis himself and his coauthors (such as Samuel Bowles) use these theories.

\section{ARE NON-ECONOMIC FACTORS DONE JUSTICE TO?}

Observing that current economic analysis is very flexible and elastic does not imply, of course, that specific economic analyses of specific "outlandish" phenomena contribute a lot to our understanding of them. One might rightly ask what is gained by garbing sociological explanations in a new "economic" dress, for example. Is our understanding of why women tend to conform to the norm of wearing left-buttoning clothes enhanced (or deepened) by saying that this is less costly for them than switching to right-buttoning clothes instead of 
saying that it is the prospect of being subjected to social disapproval that prevents them from switching to right-buttoning clothes? It rather seems to be the other way around: the "original" sociological explanation seems to be more informative than its translation into economic parlance. If this is what Fine and Milonakis mean when they argue that economic analyses of "the social" are often parasitic on work already done in other social sciences, then they are on to something real and important. But when they interpret "parasitic" in terms of exploitation and acquisition, I think they are overstating their case. As I argued above, in paraphrasing explanations that are originally given in other social sciences, these other social sciences are not thereby dispossessed by economics. More importantly, I think that the flexibility and elasticity of current economic analyses raises interesting and important issues that warrant further discussion. But I fail to see how discussing such work in terms of economics imperialism helps to bring these issues closer to a satisfactory resolution.

Observing that current economic analysis is very flexible and elastic does not imply either that specific economic analyses of specific "outlandish" phenomena are on the right track. Consider once again Levitt and Dubner's discussion of incentives and how human behavior responds to them. Levitt and Dubner argue that an incentive is simply a means of urging people to do more of one thing and less of another. Although there are some incentives that come naturally, Levitt and Dubner note that most incentives that we know of have been invented by people such as economists and politicians. Taxes and subsidies, as paradigm economic incentives, are a clear case in point. Taxes are negative incentives that, if introduced correctly, act like the proverbial stick by deterring people from doing certain things that they otherwise would have done. Subsidies are positive incentives that, if introduced correctly, act like the proverbial carrot by inducing people to do certain things they otherwise would not have done. Taxes and subsidies are artificially created rewards and punishments that change the pay-offs that agents face in their external, objective environment.

Are social and moral incentives also like that? Consider social incentives first. Sometimes it seems Levitt and Dubner argue that shame is a (and perhaps even the) social incentive. Like taxes, shame (or perhaps rather the prospect of being ashamed) might prevent people from doing things they otherwise would have done. But unlike taxes, shame itself does not seem to be something in the external objective 
environment of people. Rather, shame is something internal to people. What is external to people are the conditions or circumstances that might make people feel ashamed. Thus, what might make a big difference is whether or not people might be observed and caught by others for example in the act of cheating. As in Feldman's bagel example, the very presence of some particular person might act as an effective deterrent against cheating. So if we insist that an incentive be something objective external to the agent, the presence of people who can watch the agent's deeds rather than the agent's shame might better qualify as a social incentive.

What about moral incentives? Sometimes it seems Levitt and Dubner argue that guilt is the moral incentive. And again it is easy to see how guilt (or perhaps the anticipation of it) can act like shame and taxes in preventing people from doing things they otherwise would have done. But again, unlike taxes and like shame, guilt is something internal rather than external to agents. As Levitt and Dubner rightly note, guilt seems to be unlike shame, however, in that its occurrence is independent of whether there are other people around who can observe the agent's behavior. If people do things they deem morally wrong, they feel guilty no matter whether they are (or can be) observed. That is not to say, of course, that the inducement of guilt in people is independent altogether of the agent's objective external environment. As Levitt and Dubner rightly observe, whether or not people feel guilty might depend on the information that is provided to them. People might start feeling guilty about buying cigarettes on the black market, for example, if the government discloses the information that terrorists raise money by selling black-market cigarettes. But it does not make sense to call the provision of such information a moral incentive, I think.

Levitt and Dubner also discuss the interesting case of the Israeli daycare centers in which the introduction of a small (\$3) fine for parents who picked up their children late paradoxically led to an increase rather than a decrease in the number of late-comers. Levitt and Dubner argue that the introduction of the fine meant that a moral incentive (i.e., the guilt that parents were supposed to feel when they came late) was substituted by an economic incentive (i.e., the $\$ 3$ penalty): "For just a few dollars each day, parents could buy off their guilt" (Levitt and Dubner 2005, 19). On the basis of just the few lines they devote to this case, it is not so clear what exactly changed according to Levitt and Dubner. Is it that after the introduction of the fine, late-coming parents 
are assumed not to feel any guilt anymore? This is what Levitt and Dubner seem to suggest when they write that moral incentives are substituted by economic incentives. Or is it that parents are assumed to still feel a bit guilty, but that they came to think that by paying $\$ 3$ they could fully redeem their guilt to the day-care center and its employees? This is what Levitt and Dubner suggest when they write that the smallness of the fine signaled to the parents that late-coming was not such a big problem for the day-care center after all (so that they did not need to feel very guilty when they were late). Either way, casting the discussion in terms of moral incentives does not really contribute to its clarity.

What Levitt and Dubner's discussion of the Israeli day-care centers does make clear is that Levitt and Dubner believe there are other ways for people to put their guilty feelings to rest than by simply refraining from doing the things they deem morally wrong. Levitt and Dubner foster the impression that in the end, whether or not people's feelings of guilt prevent them from doing things they consider to be morally wrong depends on economic incentives after all. Indeed, one of the major themes in their book is that just about everyone cheats if the stakes are right (Levitt and Dubner 2005, 20). And although Levitt and Dubner allow for the possibility that "the stakes" include social factors (notably whether or not people can be observed and caught in the act of cheating), they tend to concentrate on the standard economic ones. Everything has its price, as the familiar economic saying goes, whether it be the revenues one forgoes by buying this pair of shoes rather than another or whether it be the revenues one forgoes by not plundering one's mom's purse. The assumption is that for everyone there is a point (for one person the purse should contain at least $€ 1,000$; for another at least $€ 10,000$; and for yet another perhaps at least $€ 10,000,000)$ at which the temptation to plunder the purse becomes irresistible and at which moral scruples are overcome.

Thus the take-away message of Freakonomics about human behavior, and particularly about different kinds of incentives and how they affect human behavior, is not very clear. On the one hand, Levitt and Dubner recognize that even in the presence of countervailing economic and social incentives, moral "incentives" might be strong enough for people to refrain from cheating (as in the case of Feldman's clients). How exactly moral "incentives" are supposed to do this is, as we saw, also not very clear. At best it is not worked out. At worst, it is simply confused. 
On the other hand, the general assumption seems to be that if the economic gain of cheating is high enough, nothing will stop people from cheating. It is just that the economic gains must be higher if people know there is a fair chance that cheaters will be caught and shamed or if people have strong moral reservations against cheating.

One might rightly wonder whether moral feelings and moral considerations are done justice when attempts such as Levitt and Dubner's are made to squeeze them into the standard terminology of economic analysis. This seems to be a legitimate concern of those who, like Fine and Milonakis, criticize Freakonomics for its extreme economics imperialism. But, to repeat, discussing this concern in terms of economics imperialism and its alleged attendant attributes, such as exploitation and appropriation, does not help a jot. In a sense, such discussions badly distort what is questionable about such attempts.

\section{CONCLUSION}

Books in the economics-made-fun genre should not be mistaken for papers and books in the economists-can-be-funny genre. Papers and books in the latter genre are not meant to be taken seriously. As parodies of serious academic economics papers, they are meant to make fun of economics in a light and non-condescending way. These papers and books engage in a mild form of self-mockery that is intended to amuse or entertain primarily fellow economists. By contrast, writers and protagonists of the economics-made-fun genre want their work to be taken very seriously. They think their books show that economic analysis can uncover the hidden side of all kinds of interesting phenomena. The intended audience is not so much fellow economists as those who have not yet been initiated into "thinking as an economist". The fun here is: first, with the accessible and entertaining way in which the basic economic principles are explained; second, with the recognition of the breadth of the scope of economic analysis; and third, with the sort of contrarian insights that economic analyses yield.

The books in the economics-made-fun genre want to spread the message that economic analysis is general enough to address all kinds of phenomena that are traditionally considered to be foreign to the economic domain. They furthermore want to convey that economic analyses of such "outlandish" phenomena tend to produce insights that run counter not only to conventional wisdom but also to the insights produced in other social sciences. Does this imply that books in the 
economics-made-fun genre practice, or at least reflect, economics imperialism? In this paper I have argued that this is not the case. There is no doubt that the set of phenomena made amenable to economic analysis include phenomena that were traditionally covered by other social sciences. It is also true that the economists involved often seem to believe that their discipline is superior (especially in terms of analytical rigor) to other social sciences. Yet, this does not imply that terms such as "invading", "conquering", "appropriation", and the like, which are often used to characterize "economics imperialism", are apt or accurate here.

Proponents of the economics-made-fun genre show no special interest in influencing what is going on in other sciences. They do not seem to be interested in "imposing" their approach on practitioners of other disciplines. Nor do they seem to want to enter other social sciences to take over the positions of their current practitioners and make a career there. Instead, they seem to be more concerned "collectively" about the unflattering and (in their opinion) unfair image of the dismal science that still haunts their discipline. They want to show that this image is blatantly at odds with economics as it is practiced nowadays. And "individually", it seems that young economists in particular believe they can best boost their own careers in the economics profession by tackling "outlandish" subjects. As such, the books in the economics-made-fun genre reflect the prevailing incentive structure within the economics profession and the changing perceptions of leading "mainstream economists" (especially in their roles as editors of economics journals) about what sort of work (and papers) in economics are interesting rather than a desire to invade and conquer other disciplines.

Finally, and perhaps most importantly, "economics imperialism" suggests that the intellectual transfer of ideas, concepts, insights and the like between economics and other social sciences is a one way street: that economists bring their approach and basic explanatory principles to bear on subjects that are traditionally deemed non-economic but there is no transfer in the reverse direction. This belies the fact that concepts and insights developed in other social sciences have started to find their way into economic analysis. All the work in the economicsmade-fun genre reflects this reverse transfer of concepts and insights from other social sciences into economic analysis, though admittedly to various degrees. One might argue, of course, that to date this reverse 
influence of other social sciences on economics has been very small and also that in accommodating concepts and insights from other social sciences economics has badly distorted them. These are important issues that deserve serious further discussion. But discussing them under the heading of "economics imperialism" impedes rather than helps their informed and satisfactory resolution.

\section{REFERENCES}

Akerlof, George A., and William T. Dickens. 1982. Economic consequences of cognitive dissonance. American Economic Review, 72 (3): 307-319.

Ariely, Dan. 2008. Predictably irrational: the hidden forces that shape our decisions. New York: HarperCollins.

Blinder, Alan S. 1974. The economics of brushing teeth. The Journal of Political Economy, 82 (4): 887-891.

Clotfelter, Caroline P. 1997. On the third hand: wit and humor in the dismal science. Ann Arbor: University of Michigan Press.

Coase, Ronald H. 1937. The nature of the firm. Economica, 4 (16): 386-405.

Coyle, Diane. 2007. The soulful science: what economists really do and why it matters. Princeton (NJ): Princeton University Press.

Cowen, Tyler. 2007. Discover your inner economist: use incentives to fall in love, survive your next meeting, and motivate your dentist. New York: Dutton Adult.

DiNardo, John. 2007. Interesting questions in Freakonomics. Journal of Economic Literature, 45 (4): 973-1000.

Fine, Ben, and Dimitris Milonakis. 2009. From economics imperialism to Freakonomics. New York: Routledge.

Frank, Robert H. 1988. Passions within reason. New York: W. W. Norton \& Company.

Frank, Robert H. 2007. The economic naturalist: in search of explanations for everyday enigmas. New York: Perseus Books Group.

Friedman, David D. 1996. Hidden order: the economics of everyday life. New York: HarperBusiness.

Galbraith, John K. 1958. The affluent society. Boston: Houghton Mifflin Company.

Gibbons, Robert. 2005. What is economic sociology and should any economists care? Journal of Economic Perspectives, 19 (1): 3-7.

Gintis, Herbert. 2007. A framework for the unification of the behavioral sciences. Behavioral and Brain Sciences, 30 (1): 1-61.

Gintis, Herbert. 2009. The bounds of reason: game theory and the unification of the behavioral sciences. Princeton (NJ): Princeton University Press.

Glimcher, Paul W., Michael C. Dorris, and Hannah M. Bayer 2005. Physiological utility theory and the neuroeconomics of choice. Games and Economic Behavior, 52 (2): 213-256.

Granovetter, Mark. 1985. Economic action and social structure: the problem of embeddedness. American Journal of Sociology, 91 (3): 481-510.

Hallinan, Joseph T. 2009. Why we make mistakes: how we look without seeing, forget things in seconds, and are all pretty sure we are way above average. New York: Broadway Books. 
Harbaugh, William. 2003. Economics of work and play. University of Oregon Economics Department Working Papers 2003-3. University of Oregon, Eugene, Oregon.

Harford, Tim. 2005. The undercover economist: exposing why the rich are rich, the poor are poor-and why you can never buy a decent used car! Oxford and New York: Oxford University Press.

Harford, Tim. 2008. The logic of life: the rational economics of an irrational world. New York: Random House.

Kay, John. 2003. The truth about markets: their genius, their limits, their follies. London: Allen Lane.

Krugman, Paul R. 1978. The theory of interstellar trade. Unpublished manuscript. http://www.princeton.edu/ pkrugman/interstellar.pdf (accessed June 2009).

Landsburg, Steven E. 1993. Armchair economist: economics and everyday life. New York: Free Press.

Landsburg, Steven E. 2007. More sex is safer sex: the unconventional wisdom of economics. New York: Free Press.

Lazear, Edward P. 2000. Economic imperialism. Quarterly Journal of Economics, 115 (1): 99-146.

Lehrer, Jonah. 2009. How we decide. New York: Houghton Mifflin Company.

Levitt, Steven D. 2007a. This is what happens to people who listen to too much AC/DC... Freakonomics-New York Times Blog, Aug/20/2007. http://freakonomics.blogs.nytimes.com/2007/08/20/this-is-what-happens-to-people-who-listen-totoo-much-acdc/ (accessed June 2009).

Levitt, Steven D. 2007b. There is hope for economics: the AC/DC paper was a joke. Freakonomics-New York Times Blog, Aug/21/2007.

http://freakonomics.blogs.nytimes.com/2007/08/21/there-is-hope-foreconomics-the-acdc-paperwas-a-joke/ (accessed June 2009).

Levitt, Steven D., and Stephen J. Dubner. 2005. Freakonomics: a rogue economist explores the hidden side of everything. New York: William Morrow.

Mäki, Uskali. 2002. Explanatory ecumenism and economics imperialism. Economics and Philosophy, 18 (2): 235-257.

Mäki, Uskali. 2009. Economics imperialism: concept and constraints. Philosophy of the Social Sciences, 39 (3): 351-380.

Mankiw, Greg. 2007. Is Steve Levitt ruining economics? Greg Mankiw's Blog, Apr/24/2007. http://gregmankiw.blogspot.com/2007/04/is-steve-levitt-ruining-economics.html (accessed July2009).

Marglin, Stephen A. 2008. The dismal science: how thinking like an economist undermines community. Cambridge (MA): Harvard University Press.

McCusker, James. 2007. Critical though in painfully short supply. HeraldNet, Sep/02/2007. http://www.heraldnet.com/article/20070902/BIZ/109020029/1005 (accessed June 2009).

Oxoby, Robert J. 2007. On the efficiency of AC/DC: Bon Scott versus Brian Johnson. University of Calgary Economics Discussion Paper No. 2007-08. University of Calgary, Calgary, Alberta.

Oxoby, Robert J. 2007. Comment 5. Freakonomics-New York Times Blog, Aug/21/2007. http://freakonomics.blogs.nytimes.com/2007/08/21/there-is-hope-foreconomics-the-acdc-paperwas-a-joke/\#comment-67363 (accessed June 2009). 
Ross, Don. 2008. Two styles of neuroeconomics. Economics and Philosophy, 24 (3): 473483.

Rubinstein, Ariel. 2006. Freak-Freakonomics. The Economists' Voice, 3 (9): article 7.

Scheiber, Noam. 2007. Freaks and geeks: how Freakonomics is ruining the dismal science. The New Republic, Apr/02/2007: 27-31. http://www.factsandideas.com/files/freaks_and_geeks.pdf (accessed July 2009).

Schelling, Thomas C. 1978. Micromotives and macrobehavior. New York: W. W. Norton \& Company.

Simon, Herbert A. 1991. Organizations and markets. Journal of Economic Perspectives, 5 (2): 25-44.

Stigler, George J. 1984. Economics: the imperial science? Scandinavian Journal of Economics, 86 (3): 301-313.

Thaler, Richard H., and Cass R. Sunstein. 2008. Nudge: improving decisions about health, wealth, and happiness. New Haven (CT): Yale University Press.

Ubel, Peter A. 2009. Free market madness: why human nature is at odds with economics - and why it matters. Boston: Harvard Business School Press.

Vromen, Jack J. 2007. Neuroeconomics as a natural extension of bioeconomics: the shifting scope of standard economic theory. Journal of Bioeconomics, 9 (2): 145167.

Wheelan, Charles. 2002. Naked economics: undressing the dismal science. New York: W. W. Norton \& Company.

Jack J. Vromen is professor of theoretical philosophy, dean of international affairs, and academic director of the Erasmus Institute for Philosophy and Economics (EIPE), at Erasmus University Rotterdam. His research interests are in the philosophy of economics, with an emphasis on conceptual and meta-theoretical aspects of the relation between evolutionary and economic theorizing.

Contact e-mail: <vromen@fwb.eur.nl>

Website: <www.eur.nl/fw/contact/medewerkers/vromen/> 